\title{
André Guyaux, Baudelaire et le fragment
}

\section{Ida Merello}

\section{(2) OpenEdition}

\section{Journals}

\section{Edizione digitale}

URL: http://journals.openedition.org/studifrancesi/33482

DOI: 10.4000/studifrancesi.33482

ISSN: 2427-5856

\section{Editore}

Rosenberg \& Sellier

\section{Edizione cartacea}

Data di pubblicazione: 1 décembre 2005

Paginazione: 667

ISSN: 0039-2944

\section{Notizia bibliografica digitale}

Ida Merello, «André Guyaux, Baudelaire et le fragment», Studi Francesi [Online], 147 (XLX | III) | 2005,

online dal 30 novembre 2015, consultato il 18 avril 2021. URL: http://journals.openedition.org/ studifrancesi/33482 ; DOI: https://doi.org/10.4000/studifrancesi.33482

\section{Questo documento è stato generato automaticamente il 18 avril 2021.}

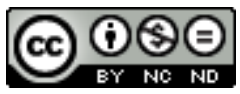

Studi Francesi è distribuita con Licenza Creative Commons Attribuzione - Non commerciale - Non opere derivate 4.0 Internazionale. 


\title{
André Guyaux, Baudelaire et le fragment
}

\author{
Ida Merello
}

\section{NOTIZIA}

ANDRÉ GUYAUX, Baudelaire et le fragment, in Théorie et pratique du fragment, Genève, Slatkine, pp. 137-148.

1 L'A. fa una breve storia del termine nell'accezione del XIX secolo, ricordando come esso avesse da un lato una valenza esotica o archeologica (prediletta da Gautier nei suoi racconti fantastici), dall'altro designasse, in senso editoriale, un estratto. Baudelaire usa il termine frammento per i testi che pubblica sulle riviste, assimilando ad esempio i suoi poèmes en prose a un corpo cui si potevano togliere le vertebre e ridurre a pezzi mantenendo intatto il senso di ciascuna parte. Nella corrispondenza utilizza tre volte il termine: si tratta di occorrenze tardive, tra il '64 e il '66, quando l'idea di pubblicare lo Spleen de Paris sembra realizzarsi. 